\title{
Desain Kapal Bulk Carrier Guna Pemenuhan Kebutuhan Batubara PLTU Sudimoro Pacitan
}

\author{
Fathan Nurudin dan Hasanudin \\ Departemen Teknik Perkapalan, Institut Teknologi Sepuluh Nopember (ITS) \\ e-mail: hasanudin@na.its.ac.id
}

\begin{abstract}
Abstrak-Indonesia merupakan negara penghasil batubara peringkat ke lima di dunia dan batubara dapat digunakan dalam proses elektrifikasi untuk mendukung pertumbuhan di wilayah Jawa Timur dan Bali. Salah satu pemanfaatan batubara yaitu untuk pembangkit tenaga listrik yaitu PLTU Pacitan yang merupakan salah satu pembangkit tenaga listrik di Jawa Timur yang memiliki dua pembangkit listrik berkapasitas 315 MW. PLTU Pacitan membutuhkan bahan bakar batubara dengan jumlah 8,000 ton perharinya untuk memenuhi pasokan listrik di wilayah Jawa Timur dan Bali. Dan beberapa jenis moda transportasi yang digunakan saat ini untuk menyuplai batubara ke PLTU Pacitan antara lain, Tug \& Barge, Self Propeller Barge (SPB), dan kapal Bulk Carrier. Namun melihat keadaan saat ini banyak terjadi perubahan kondisi alam yang semakin tidak menentu seperti gelombang tinggi pada waktu tertentu, sehingga pemilihan penggunaan moda transportasi tongkang dan SPB harus dilakukan evaluasi ulang karena pada waktu tertentu, cuaca buruk menyebabkan kapal tongkang tidak dapat berlayar. PT. Arutmin Indonesia merupakan salah satu pemasok batubara PLTU Pacitan yang terletak pada provinsi Kalimantan Selatan sebagai acuan rute kapal. Dengan mendesain bulk carrier ini diharapkan dapat menjadi solusi operasional kapal pada cuaca buruk dan dapat difungsikan pada tiap waktu. Penentuan payload dari bulk carrier ini berdasarkan nilai kebutuhan pasokan tiap tahun dan penentuan ukuran utama kapal menggunakan kapal pembanding yang disesuaikan dengan kondisi perairan pada saat beroperasi dengan metode regresi linear. Ukuran utama yang memenuhi kriteria teknis dan regulasi adalah $\mathrm{Lpp}=$ $162.7 \mathrm{~m} ; \mathrm{B}=\mathbf{2 5 . 0} \mathrm{m} ; \mathrm{H}=\mathbf{1 4 . 2} \mathrm{m} ; \mathrm{T}=10.0 \mathrm{~m}$. Tinggi freeboard minimum yang didapatkan yaitu $3274 \mathrm{~mm}$, tonase kotor kapal mencapai 15,640.76 ton, Bobot Mati Kapal yaitu 29615,982 ton, kondisi stabilitas kapal memenuhi kriteria IS Code dan Grain Code, dan probabilitas deck wetness memenuhi kriteria, yaitu untuk heading $90^{\circ}$ dengan nilai 0.012 , heading $135^{\circ}$ dengan nilai 0.014 , dan heading $180^{\circ}$ dengan nilai 0.039. Dengan kurs USD terhadap Indonesia Rupiah 14,027 didapat Biaya pembangunan sebesar Rp. 106,425,619,372.80.
\end{abstract}

Kata Kunci-Bulk Carrier, Pembangkit Listrik, Batubara, Stabilitas, Deck Wetness.

\section{PENDAHULUAN}

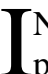
NDONESIA merupakan negara penghasil batubara peringkat ke lima di dunia dan diprediksi jumlah produksi batubara lebih dari 386 juta ton setiap tahun. Dengan cadangan batubara di Indonesia saat ini diperkirakan 5.5 miliar ton. Batubara merupakan salah satu produk pertambangan yang kerap digunakan sebagai sumber energi pada sektor pembangkit listrik. Kebutuhan batubara tersebut diperkirakan akan terus meningkat ketika batubara digunakan sebagai bahan bakar utama pembangit listrik menggantikan minyak karena biaya lebih tinggi dari batubara. PLTU Pacitan merupakan salah satu pembangkit listrik yang dicanangkan untuk pemenuhan kebutuhan listrik yang melingkupi wilayah Jawa Timur dan Bali. PLTU
Pacitan memiliki dua unit pembangkit listrik berkapasitas masing-masing $315 \mathrm{MW}$ yang membutuhkan 8000 ton batubara perharinya untuk memenuhi pasokan listrik di wilayah Jawa Timur dan sekitarnya. Suplier bahan bakar batubara PLTU Pacitan berasal dari PT.Arutmin Indonesia dan PT. Darma Henwa.

Jenis moda transportasi yang digunakan saat ini untuk memsaok batubara ke PLTU Pacitan antara lain, Tug \& Barge, Self Propeller Barge (SPB), dan kapal Bulk Carrier. Namun melihat keadaan saat ini banyak terjadi perubahan kondisi alam yang semakin tidak menentu, sehingga pemilihan penggunaan moda transportasi tongkang harus dilakukan evaluasi ulang. Pada waktu tertentu cuaca buruk menyebabkan pihak administrasi pelabuhan melarang kapal tongkang untuk tidak berlayar, dan memilih berlabuh menunggu cuaca yang baik. Oleh karena itu, dengan perencanaan desain kapal Bulk Carrier diharapkan kapal dapat berlayar pada cuaca buruk dan menjadi moda transportasi alternatif menggantikan kapal tongkang yang kurang difungsikan disetiap waktu dapat menghambat proses pasokan batubara.

Tujuan yang akan dicapai pada penulisan ini adalah merencanakan payload kapal, mendapatkan ukuran utama bulk carrier yang sesuai untuk memasok batubara dari Kalimantan ke dermaga PLTU Pacitan, mendapatkan perhitungan teknis hambatan, dan daya mesin, analisis freeboard, stabilitas dan seakeeping kapal yang sesuai dengan aturan. Selanjutnya merencanakan desain rencana garis, rencana umum, model 3D, dan menghitung biaya pembangunan bulk carrier.

\section{TINJAUAN PUSTAKA}

\section{A. Pendekatan Desain}

Pada proses pembangunan kapal, persyaratan utama yang harus dilakukan adalah proses desain kapal. Desain merupakan tahapan yang menjadi dasar dalam mengubah permintaan pemilik kapal kedalam bentuk gambar, spesifikasi dan data lainnya untuk membangun sebuah kapal. Konsep desain spiral menitikberatkan pada masalah desain yang saling berurutan dan peningkatan detail masing masing yang kemudian membentuk spiral sampai memperoleh desain tunggal yang memenuhi semua kendala dan pertimbangan bisa tercapai, seperti yang terlihat pada Gambar 1. Terdapat beberapa cakupan yang pertama adalah Concept design dimana ini merupakan tahap pertama dalam proses desain yang menterjemahkan mission requirement atau permintaan pemilik kapal ke dalam ketentuanketentuan dasar dari kapal yang akan direncanakan sehingga menghasilkan ukuran utama seperti panjang, lebar, tinggi, sarat, finnes dan fullness power, karakter lainnya dengan tujuan untuk memenuhi kecepatan, range (endurance), 


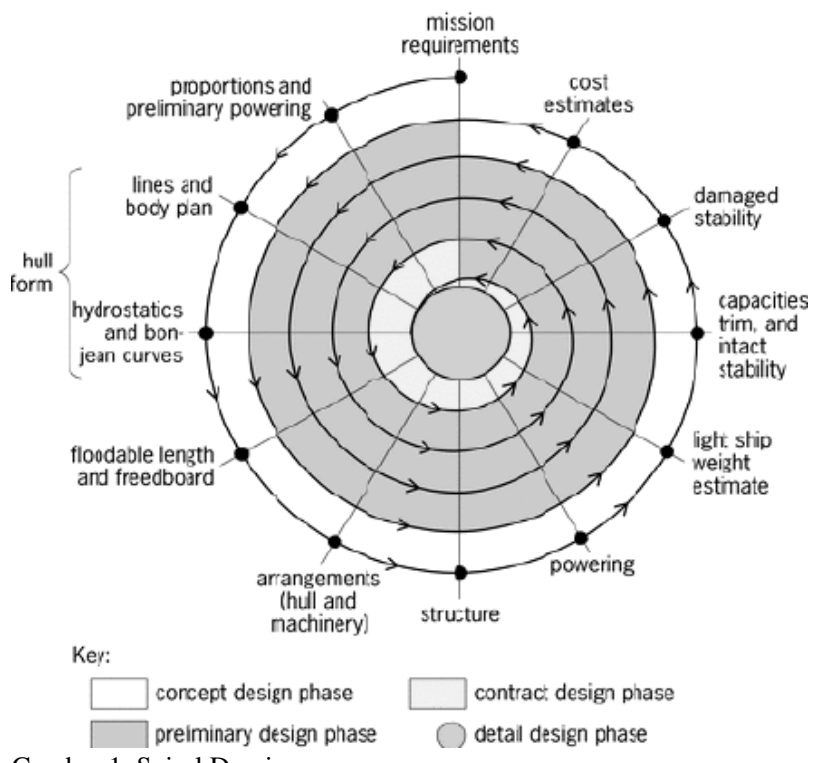

Gambar 1. Spiral Desain.

kapasitas, dan deadweight. Selanjutnya yaitu preliminary desain yang merupakan langkah kelanjutan dari concept desain untuk memeriksa kembali ukuran dasar kapal yang dikaitkan dengan performance. Pemeriksaan ulang terhadap panjang, lebar, daya mesin, deadweight yang diharapkan tidak banyak merubah pada tahap ini.

Selanjutnya yaitu tahap contract design yang merupakan tahap merencanakan atau menghitung lebih teliti hull form (bentuk badan kapal) dengan memperbaiki lines plan, tenaga penggerak dengan menggunakan model test, seakeeping dan maneuvering karakteristik, pengaruh jumlah propeller terhadap badan kapal, detail konstruksi, estimasi berat dan titik berat yang dihitung berdasarkan posisi dan berat masing-masing item dari konstruksi. General Arrangement detail dibuat juga pada tahap ini. Kepastian kapasitas permesinan, bahan bakar, air tawar dan ruang-ruang akomodasi. Kemudian dibuat spesifikasi rencana standart kualitas dari bagian badan kapal serta peralatan. Berikutnya tahap akhir dari perencanaan kapal adalah pengembangan detail gambar kerja. Hasil dari langkah ini adalah berisi petunjuk/instruksi mengenai instalsi dan detail konstruksi kepada tukang pasang (fitter), tukang las (welder), tukang perlengkapan (outfitter), tukang pelat, penjual mesin, tukang pipa dan lain-lainnya. Langkah ini perubahan dari engineer (ahli teknik) untuk tukang, oleh karena itu tidak bisa diinterpelasikan (dirubah).

\section{B. Bulk Carrier}

Bulk carrier merupakan kapal yang khusus digunakan untuk mengangkut muatan curah seperti biji tambang (batubara). Kapal ini dapat dimanfaatkan oleh perusahaan tambang, atau pupuk untuk mengangkut produk dari perusahaan tersebut. Bulk carrier pada umumnya memiliki ukuran yang cukup besar dan panjang lebih dari 100 meter. Kapal bulk carrier mempunyai stabilitas yang baik karena pada titik M berada diatas titik $\mathrm{G}$ dalam semua kondisi [1]. Dibandingkan dengan tug \& barge dan self-propelled barge (SPB), kapal bulk carrier dianggap kapal yang dapat melewati perairan memiliki tinggi gelombang diatas 4 meter.

\section{Tinggi Gelombang Perairan Indonesia}

Perairan Indonesia memiliki karakteristik gelombang dengan ketinggian yang bervariasi sepanjang tahun,

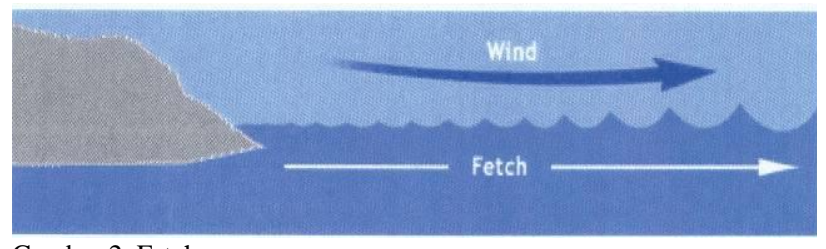

Gambar 2. Fetch.

tergantung dari kekuatan angin dan permukaan yang terjadi sesuai angin musiman yang sedang berlangsung. Kondisi tinggi gelombang ini sangat dipengaruhi oleh tiga faktor penyebab utama diantaranya adalah kecepatan angin, lamanya angin berhembus (duration), dan jarak dari tiupan angin pada perairan terbuka (fetch). Sedangkan panjang Fetch adalah jarak tempuh perjalanan gelombang dari awal pembangkitannya. Fetch ini dibatasi oleh bentuk daratan yang mengelilingi laut. Semakin panjang jarak fetchnya maka semakin besar gelombang yang terjadi [2].

Di Indonesia terdapat dua pola angin musiman (monsum/muson) yaitu musim angin barat (monsum Asia) dan musim angin timur (monsum Australia) yang terjadi secara periodik (kurang lebih 3 bulan). Pada monsum Asia, angin permukaan berhembus dari belahan utara equator menuju belahan selatan equator pada Bulan Desember, Januari, dan Februari. Sedangkan munsun Australia angin permukaan yang berhembus dari arah sebaliknya yaitu dari belahan selatan equator menuju belaha utara equator pada Bulan Juni, Juli, dan Agustus. Periode lainnya adalah dua periode yang disebut dengan periode peralihan yang terjadi diantara periode monsum Asia dan monsun Australia yaitu pada Bulan Maret, April, Mei, September, Oktober, dan November. Gelombang tinggi sering terjadi pada periode monsun Asia sekitar Bulan Januari dan Munson Australia sekitar Bulan Juli [1]. Walaupun demikian ketinggian gelombang di wilayah perairan terbuka lebih tinggi bila dibandingkan dengan perairan antar pulau. Hal ini dikarenakan adanya perbedaan panjang fetch yang terbentuk di wilayah perairan tersebut.

\section{PLTU Sudimoro Pacitan}

PLTU Pacitan terletak di laut selatan pulau Jawa, Desa Sukorejo, Kecamatan Sudimoro. Secara astronomis, PLTU Pacitan terletak pada $8^{\circ} 15^{\prime} 38.7^{\prime \prime}$ Selatan dan $111^{\circ} 22^{\prime} 28.5^{\prime \prime}$ Timur. PLTU Pacitan dapat ditempuh dengan jarak $30 \mathrm{~km}$ ke arah timur dari Kabupaten Pacitan, Jawa Timur, seperti yang terlihat pada Gambar 3. Secara geografis, PLTU Pacitan ini terletak dengan samudera hindia. PLTU ini merupakan salah satu proyek yang dicanangkan dalam program percepatan pembangunan pembangkit listrik 10 MW oleh pemerintah pada saat itu. Energi listrik pada PLTU Pacitan disalurkan melalui Saluran Udara Tegangan Tinggi (SUTT) $150 \mathrm{kV}$ sepanjang 35,65 km dari Gardu Induk di PLTU menuju Gardu induk Pacitan Baru, dan sepanjang 84,8 km menuju Gardu Induk Wonogiri. PLTU Pacitan miliki fasilitas bongkar pada dermaga yaitu dengan menggunakan grab ship unloader dengan tipe ZQX1250 bridge-type grab ship unloader with four winding drums and steel cable hauled crab. Grab ship unloader ini berkapasitas 19 ton untuk sekali angkut.

\section{E. Terminal Batubara Pulau Laut}

Terminal batubara Pulau Laut Utara merupakan terminal yang dimiliki oleh PT. Arutmin Indonesia yang secara astronomis terletak pada $03^{\circ} 12^{\prime} 00^{\prime}$ ' Selatan dan $116^{\circ} 17^{\prime}$ 00" Timur. Terminal batubara Pulau Laut Utara memiliki 


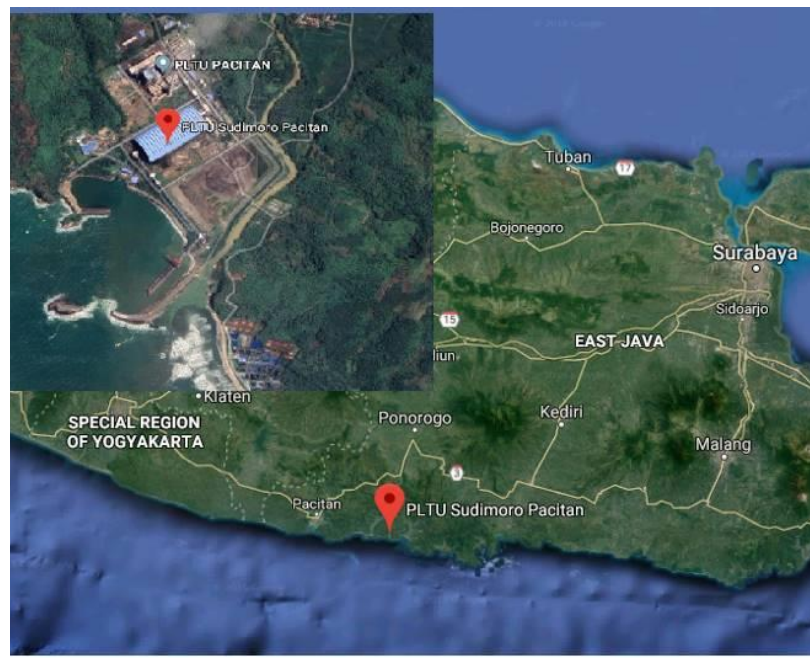

Gambar 3. PLTU Sudimoro Pacitan.

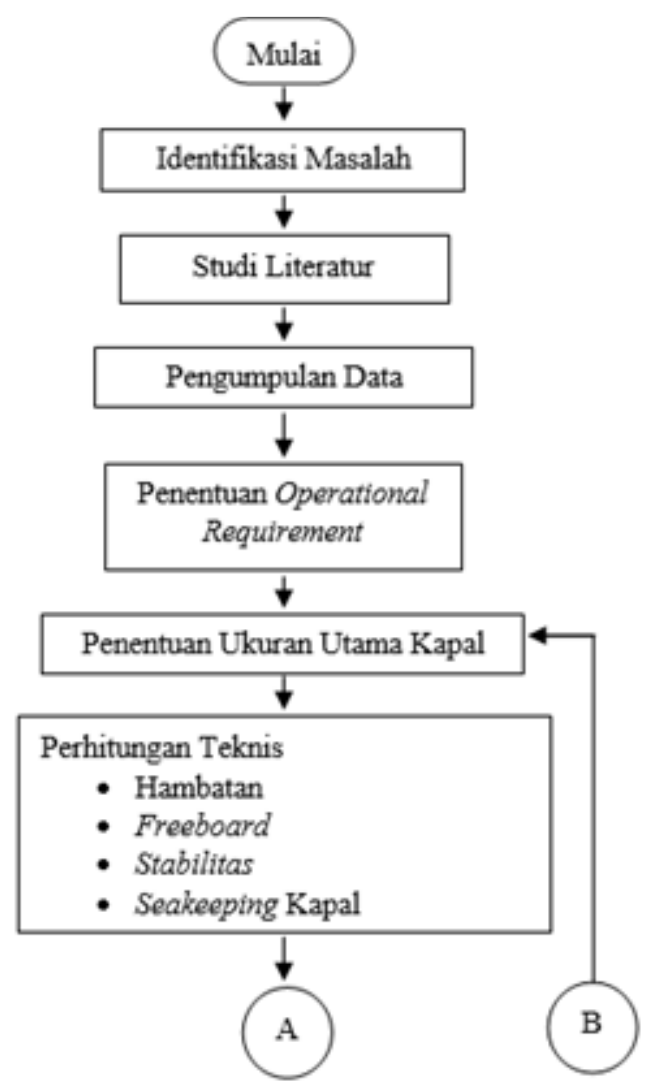

Gambar 5. Diagram Alir Metodologi Penelitian

stockpile batubara berkapasitas 600.000 ton. Terminal ini juga dapat melayani kapal bulk carrier hingga 150.000 DWT. Terdapat beberapa tambang batubara yang dimiliki oleh PT. Arutmin Indonesia, yaitu Tambang Senakin, Tambang Satui, Tambang Kintap, Tambang Asam Asam, Tambang Batulicin. Produk yang dihasilkan dari pertambangan Senakin dan Satui diangkut menggunakan truk dan menempuh perjalanan antara $9 \mathrm{~km}$ hingga $20 \mathrm{~km}$, setelah itu ditimbun di salah satu dari empat pelabuhan tongkang Arutmin. Batubara dari Senakin Timur dibawa ke pelabuhan tongkang Sembilang yang berjarak kira-kira 27 km sedangkan batubara Senakin Barat diangkut sejauh 15,5 km untuk ditimbun di pelabuhan tongkang Air Tawar 2. Batubara Satui dibawa ke pelabuhan tongkang Muara Satui yang berjarak kira-kira $45 \mathrm{~km}$ dimana disitu terdapat

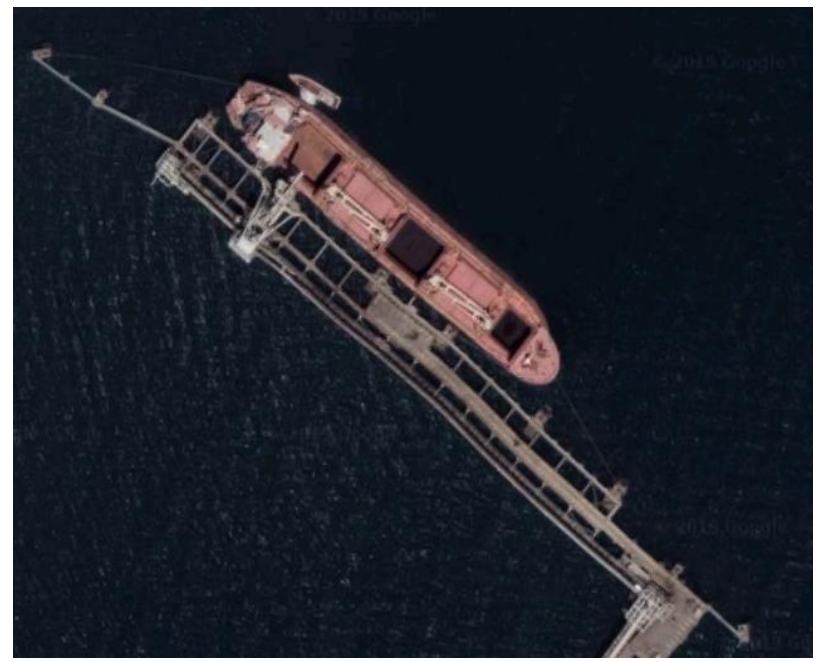

Gambar 4. Terminal Batubara Pulau Laut

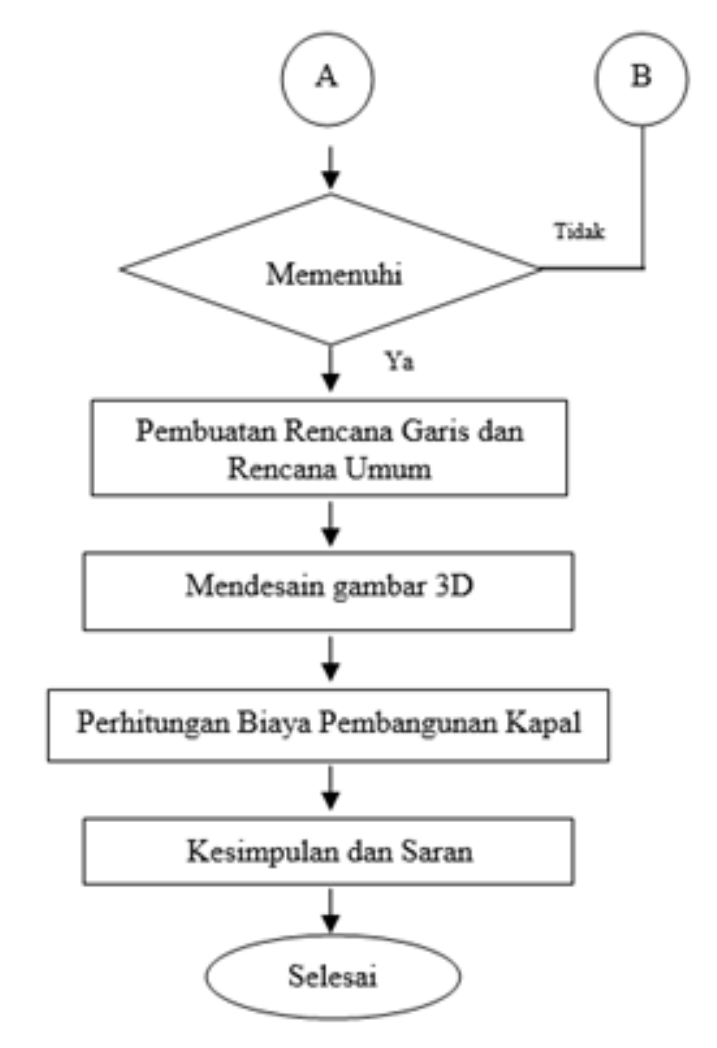

fasilitas mesin penghancur. Batubara yang sudah diproses lalu ditimbun lebih dahulu sebelum dimuat ke kapal tongkang.

Batubara Batulicin diangkut ke pelabuhan tongkang Muara Satui yang berjarak kira-kira $70 \mathrm{~km}$ dimana disitu terdapat fasilitas mesin penghancur. Batubara yang sudah diproses lalu ditimbun lebih dahulu sebelum dimuat ke kapal tongkang. Di pelabuhan kapal tongkang, batubara dimuat kedalam armada kapal tongkang Arutmin yang memiliki kapasitas 7.000 DWT atau 3.500 DWT, atau kapal tongkang beratap datar untuk transhipping atau pengiriman langsung ke pelanggan. Dari pusat ini, batubara biasanya dikirim langsung ke pelanggan dalam negeri maupun regional, melalui Terminal Batubara Pulau Laut Utara (NPCLT), atau pusat pengalihan kapal. 


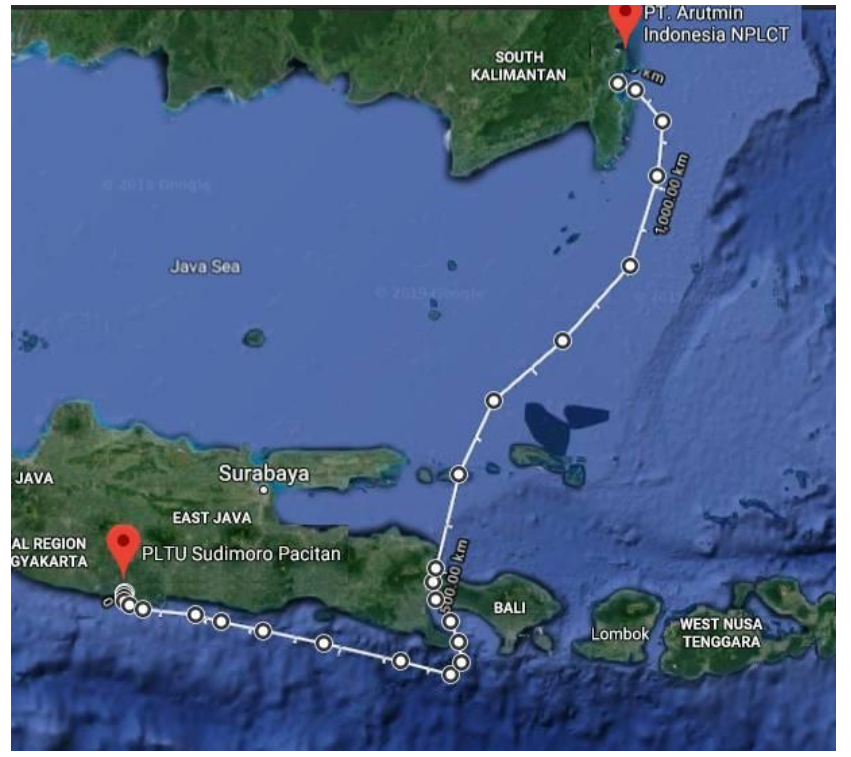

Gambar 6. Rute Pelayaran

\section{METODOLOGI}

Secara Umum, alur pengerjaan penelitian ini dapat dilihat pada Gambar 5. Tahap pengerjaan studi ini dimulai dari identifikasi masalah yaitu merumuskan permasalahan dari latar belakang yang ada, dan bertujuan untuk mengetahui permasalahan yang akan diselesaikan. Selanjutnya yaitu tahapan studi literatur yang dimaksudkan untuk mengumpulkan teori dan referensi tinjauan wilayah, teori dasar desain kapal, dan teori seakeeping kapal. Lalu tahapan selanjutnya yaitu pengumpulan data yang mana pada studi ini menggunakan metode primer dan sekunder. Pada tahap selanjutnya yaitu penentuan operational requirements yang terdiri dari penentuan kecepatan dinas kapal, rute pelayaran kapal, penentuan payload kapal. Lalu pada tahap selanjutnya dilakukan penentuan ukuran utama kapal dengan menggunakan metode regresi linier terhadap beberapa kapal pembanding, lalu dilakukan pengecekan rasio kapal. Tahapan selanjutnya dilakukan perhitungan teknis yaitu melakukan perhitungan hambatan dan propulsi kapal, perhitungan dan pengecekan berat kapal, freeboard, stabilitas, dan analisis deck wetness dimaksudkan untuk mengetahui gerakan kapal pada saat terkena gelombang signifikan 4 meter sesuai dengan kondisi perairan di berbagai macam kondisi heading. Analis menggunakan bantuan software Maxsurf Motion. Tahap selanjutnya dilakukan tahap desain yaitu desain lines plan, General arrangement, dan Model 3D. Selanjutnya dilakukan tahapan perhitungan biaya pembangunan kapal ini dimaksudkan untuk mengetahui estimasi biaya pembangunan kapal. Perhitungan estimasi biaya dilakukan dengan cara menghitung biaya material kapal berdasarkan harga di pasaran, keuntungan galangan, dan overhead cost.

\section{ANALISIS TEKNIS}

\section{A. Penentuan Operational Requirement}

Operational Requirements merupakan tahapan dasar yang diperlukan untuk mendesain sebuah kapal. Hal ini berisi persyaratan yang meliputi aspek-aspek operasional kapal yang disesuaikan dengan kebutuhan dan standard yang berlaku.
Tabel 1.

Ukuran Utama Awal Kapal

\begin{tabular}{rrccc}
\hline \hline $\mathrm{LoA}(\mathrm{m})$ & $\mathrm{L}_{\mathrm{PP}}(\mathrm{m})$ & $\mathrm{B}(\mathrm{m})$ & $\mathrm{T}(\mathrm{m})$ & $\mathrm{H}(\mathrm{m})$ \\
\hline 169.5 & 162.7 & 25 & 10 & 14.2 \\
\hline \hline
\end{tabular}

Tabel 2.

Pemeriksaan Ukuran Utama

\begin{tabular}{cccc}
\hline \hline Rasio & Nilai & Syarat & Keterangan \\
\hline $\mathrm{L} / \mathrm{B}=$ & 6.51 & $5.1 \leq \mathrm{L} / \mathrm{B} \leq 7.1$ & OK \\
$\mathrm{B} / \mathrm{T}=$ & 2.49 & $2.4 \leq \mathrm{B} / \mathrm{T} \leq 3.2$ & OK \\
$\mathrm{L} / \mathrm{T}=$ & 16.21 & $10 \leq \mathrm{L} / \mathrm{T} \leq 30$ & OK \\
$\mathrm{L} / \mathrm{H}=$ & 11.46 & $\mathrm{~L} / \mathrm{H} \leq 16$ & OK \\
$\mathrm{B} / \mathrm{H}=$ & 1.76 & $1.65 \leq \mathrm{B} / \mathrm{H} \leq 1.88$ & OK \\
\hline \hline
\end{tabular}

Tabel 3.

Rekapitulasi Berat Kapal

\begin{tabular}{clcc}
\hline \hline No & Komponen Berat Kapal & Nilai & Unit \\
\hline 1 & Berat Kapal Bagian DWT & 27041.812 & ton \\
2 & Berat Kapal Bagian LWT & 8408.19 & ton \\
& Total & 35450 & ton \\
& Displacement Kapal & 35992.69 & ton \\
& Koreksi displasment & 1.5 & $\%$ \\
\hline \hline
\end{tabular}

\section{1) Penentuan Rute Pelayaran}

Kapal Bulk Carrier dengan memuat batubara untuk studi ini akan direncanakan beroperasi pada PLTU Pacitan. Kapal ini akan mengangkut batubara dari Terminal Batubara Ujung Laut menuju PLTU Pacitan seperti yang ditunjukan oleh Gambar 6. Kapal Bulk Carrier pada studi ini berlayar mulai dari Terminal batubara Pulau Laut menuju PLTU Pacitan yang berjarak $1182 \mathrm{~km}$ atau 638.22 nautical miles seperti terlihat pada Gambar 6 tentang rute pelayaran dari kapal.

2) Penentuan Payload

Payload kapal merupakan kapasitas muatan yang diangkut oleh kapal dengan jenis muatan tertentu sesuai dengan tipe kapal yang digunakan. Kapasitas maksimum kapal dapat memasuki pelabuhan bongkar PLTU Pacitan yaitu 30.000 DWT. Penentuan payload kapal menggunakan pendekatan perhitungan jumlah pengiriman dengan kapasitas payload untuk satu tahun. Kebutuhan yang digunakan sebagai acuan penentuan payload adalah selisih terbesar antara kebutuhan dan realisasi yaitu pada tahun 2017 dengan kurangnya kebutuhan sebesar 753.861,372 ton. Dari tabel jumlah trip dengan kapasitas payload satu kapal, dipilih kapal dengan muatan 26.924 ton dan 28 kali trip yang telah diperhitungkan perencanaan waktu pengirimannya dalam setahun. Diperoleh DWT kapal yaitu 29.616 ton, yang mana hal itu sesuai dengan ukuran maksimum DWT kapal yang dapat memasuki pelabuhan bongkar PLTU Pacitan dengan kapasitas 30.000 ton.

3) Penentuan Kecepatan Kapal

Dengan ketentuan rute kapal yang digunakan sebagai acuan jarak tempuh, kecepatan angkut untuk menentukan waktu yang dibutuhkan dalam kegiatan loading dan unloading lalu direncanakan jumlah trip per tahun, maka didapatkan perencanaan kecepatan operasional kapal. Kapal Bulk Carrier dapat melaju hingga kecepatan 15 knot [3]. Dalam studi ini kecepatan operasional kapal yang ditentukan yaitu 12 knot yang diharapkan mampu memenuhi kebutuhan batubara PLTU Pacitan.

\section{B. Penentuan Ukuran Utama}

Penentuan ukuran utama bulk carrier ini menggunakan metode regresi linear. Setelah dilakukan perhitungan, 
Tabel 4.

Rekapitulasi Stabilitas berdasarkan IS 2008 Code

\begin{tabular}{ccccrrrr}
\hline \hline \multirow{2}{*}{ No. } & \multirow{2}{*}{ Criteria } & \multirow{2}{*}{ Value } & \multirow{2}{*}{ Units } & \multicolumn{3}{c}{ Actual Condition } & \multirow{2}{*}{ Status } \\
\cline { 5 - 6 } & & & Loadcase 1 & Loadcase 2 & Loadcase 3 & \\
\hline 1 & Area 0 to 30 or GZmax $\geq$ & 3.151 & m.deg & 25,727 & 25,549 & 25,470 & Pass \\
2 & Area 0 to 40 $\geq$ & 5.157 & m.deg & 45,749 & 45,750 & 45,664 & Pass \\
3 & Area 30 to 40 $\geq$ & 1.719 & m.deg & 20,162 & 20,200 & 20,194 & Pass \\
4 & Max GZ at 30 or greater $\geq$ & 1.71 & $\mathrm{~m}$ & 2,330 & 2,336 & 2,335 & Pass \\
5 & Angle of maximum GZ $\geq$ & 25 & deg & 49,100 & 49,100 & 49,100 & Pass \\
6 & Initial GMt $\geq$ & 0.15 & $\mathrm{~m}$ & 2,969 & 2,959 & 2,944 & Pass \\
\hline \hline
\end{tabular}

Tabel 5.

Rekapitulasi Stabilitas berdasarkan IS 2008 Code

\begin{tabular}{ccccrrrr}
\hline \hline \multirow{2}{*}{ No. } & \multirow{2}{*}{ Criteria } & \multirow{2}{*}{ Value } & \multirow{2}{*}{ Units } & \multicolumn{3}{c}{ Actual Condition } & \multirow{2}{*}{ Status } \\
\cline { 5 - 6 } & & & Loadcase 4 & Loadcase 5 & Loadcase 6 & \\
\hline 1 & Area 0 to 30 or GZmax $\geq$ & 3.151 & m.deg & 91,993 & 93,006 & 93,621 & Pass \\
2 & Area 0 to 40 $\geq$ & 5.157 & m.deg & 138,243 & 139,464 & 140,094 & Pass \\
3 & Area 30 to 40 $\geq$ & 1.719 & m.deg & 46,250 & 46,457 & 46,473 & Pass \\
4 & Max GZ at 30 or greater $\geq$ & 1.71 & $\mathrm{~m}$ & 4,620 & 4,637 & 4,636 & Pass \\
5 & Angle of maximum GZ $\geq$ & 25 & deg & 35,500 & 34,500 & 34,500 & Pass \\
6 & Initial GMt $\geq$ & 0.15 & $\mathrm{~m}$ & 14,955 & 15,167 & 15,314 & Pass \\
\hline \hline
\end{tabular}

Tabel 6.

Rekapitulasi Stabilitas berdasarkan IS 2008 Code \& Grain Code

\begin{tabular}{|c|c|c|c|c|c|c|c|}
\hline \multirow{2}{*}{ No. } & \multirow{2}{*}{ Criteria } & \multirow{2}{*}{ Value } & \multirow{2}{*}{ Units } & \multicolumn{3}{|c|}{ Actual Condition } & \multirow{2}{*}{ Status } \\
\hline & & & & Loadcase 7 & Loadcase 8 & Loadcase 9 & \\
\hline 1 & Area 0 to $30 \geq$ & 3.151 & m.deg & 25,727 & 28,657 & 36,49 & Pass \\
\hline 2 & Area 0 to $40 \geq$ & 5.157 & m.deg & 45,854 & 53,911 & 67,068 & Pass \\
\hline 3 & Area 30 to $40 \geq$ & 1.719 & m.deg & 20,126 & 25,255 & 30,578 & Pass \\
\hline 4 & Max GZ at 30 or greater $\geq$ & 1.71 & $\mathrm{~m}$ & 2,33 & 2,976 & 3,547 & Pass \\
\hline 5 & Angle of maximum $G Z \geq$ & 25 & deg & 49,1 & 47,300 & 47,3 & Pass \\
\hline 6 & Initial $G M t \geq$ & 0.15 & $\mathrm{~m}$ & 2,997 & 3,221 & 4,147 & Pass \\
\hline 7 & Angle of grain shift $\leq$ & 12 & deg & 4,68 & 5,86 & 6,41 & Pass \\
\hline 8 & Residual Area $\geq$ & 0.075 & m.rad & 1,02 & 0,74 & 0,58 & Pass \\
\hline
\end{tabular}

didapatkan ukuran utama awal kapal seperti yang ditunjukkan pada Tabel 1.

\section{Pemeriksaan Ukuran Utama Kapal}

Setelah mendapatkan ukuran utama kapal, dilakukan pemeriksaan ukuran utama kapal. Rasio ukuran kapal yang didapatkan untuk bulk carrier ditunjukkan pada Tabel 2.

\section{Perhitungan Hambatan dan Propulsi Kapal}

Perhitungan hambatan total dilakukan dengan metode Holtrop. Didapatkan nilai hambtan total sebesar $366.90 \mathrm{kN}$. Setelah didapat nilai hambatan total dapat dihitung kebutuhan power kapal sebesar $4770 \mathrm{~kW}$ atau 6396.66 HP. Sedangkan generator kapal yang dibutuhkan adalah 1096 KW atau 1494 HP.

\section{E. Perhitungan dan Pengecekan Berat Kapal}

Perhitungan berat kapal dibagi menjadi 2 yaitu DWT dan LWT. Dimana DWT adalah berat muatan kapal dan consumable serta LWT adalah berat kapal kosong. Hasil perhitungan dapat dilihat pada Tabel 3.

\section{F. Perhitungan dan Pengecekan Freeboard}

Perhitungan lambung timbul dilakukan berdasarkan aturan dan standar pada International Convention on Load Lines 1966 and Protocol of 1988. Kapal bulk carrier pada perhitungan lambung timbul termasuk kategori kapal tipe B. Hasil perhitungan lambung timbul minimum yang telah dilakukan mendapatkan nilai $3.28 \mathrm{~m}$ dan untuk freeboard actual didapat nilai $4.16 \mathrm{~m}$ dengan itu actual freeboard lebih dari freeboard minimum. Oleh karena itu kapal bulk carrier telah memenuhi persyaratan lambung timbul yang sesuai dengan ICLL 1966.

\section{G. Perhitungan dan Pengecekan Stabilitas}

Stabilitas kapal merupakan kemampuan kapal atau benda apung untuk kembali ke kondisi awal, setelah diberikan gaya atau gangguan, sehingga perhitungan stabilitas merupakan salah satu komponen yang paling penting dalam proses teknis perancangan kapal. Pada Tabel 4 dan Tabel 5 ditunjukkan rekapitulasi perhitungan stabilitas dengan mengacu IS Code 2008. Pada loadcase 1 merupakan kasus dimana muatan $100 \%$, dan bahan bakar $100 \%$, loadcase 2 merupakan kasus di mana muatan $100 \%$ dan bahan bakar $50 \%$, loadcase 3 merupakan kasus di mana muatan $100 \%$ dan bahan bakar $10 \%$, loadcase 4 merupakan kasus di mana muatan $0 \%$, dan bahan bakar $100 \%$. loadcase 5 merupakan kasus di mana muatan $0 \%$, dan bahan bakar $50 \%$, loadcase 6 merupakan kasus di mana muatan $0 \%$, dan bahan bakar $10 \%$.

Pada saat kapal diberikan muatan kemungkinan akan mengalami cargo shifting maka diperlukan pengecekan stabilitas pada muatan yang mengalami pergeseran dengan cara mencari residual area, dan angle of heel pada saat grain shifting tidak diizinkan bila nilainya lebih dari $12^{\circ}$ sesuai dengan Grain International Code for the safe carriage of grain in bulk-Res. MSC. 23 (59). Pada Tabel 6 ditunjukkan rekapitulasi perhitungan stabilitas dengan mengacu pada IS Code dan Grain Code. Pada loadcase 7 merupakan kasus dimana muatan $100 \%$, dan bahan bakar $100 \%$, loadcase 8 merupakan kasus dimana muatan $75 \%$, 


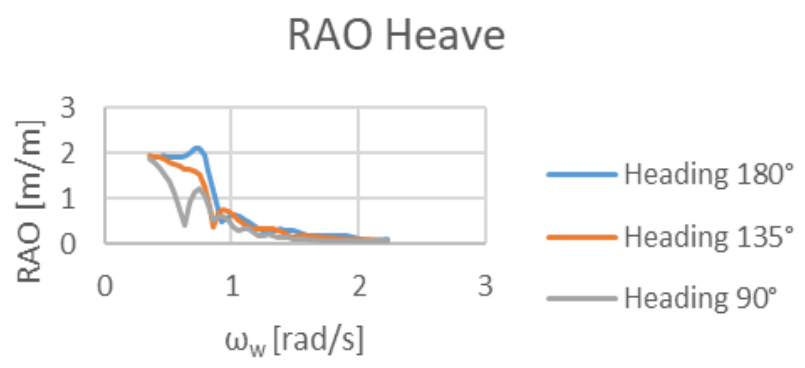

Gambar 7. RAO Heave Bulk Carrier

\section{RAO Pitch}

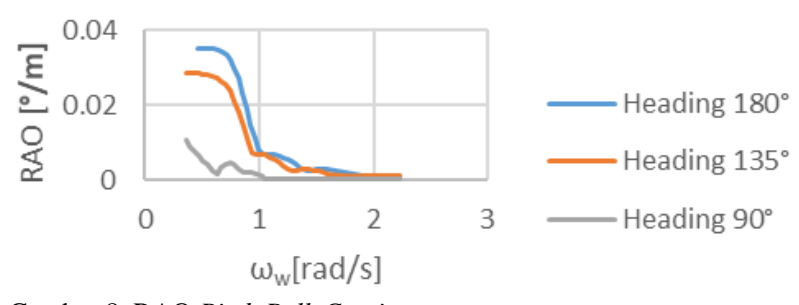

Gambar 8. RAO Pitch Bulk Carrier

Tabel 7.

Rekapitulasi Luasan Relative Bow Motion Spectrum

\begin{tabular}{clcc}
\hline \hline No & Heading $\left[^{\circ}\right]$ & Luasan $\left(\mathrm{m}_{0}\right)$ & Unit \\
\hline 1 & 180 & 10.917 & $\mathrm{~m}^{2}$ \\
2 & 135 & 8.255 & $\mathrm{~m}^{2}$ \\
3 & 90 & 7.926 & $\mathrm{~m}^{2}$ \\
\hline \hline
\end{tabular}

dan bahan bakar 100\%, loadcase 9 merupakan kasus dimana muatan $50 \%$, dan bahan bakar $100 \%$.

\section{H. Analisa Seakeeping}

Analisa seakeeping pada studi ini memperhitungkan deck wetness yang berfungsi untuk pertimbangan operasional kapal yang dipengaruhi oleh gelombang laut dititik tinjauan. Kondisi bulk carrier dianggap baik apabila probabilitas deck wetness dibawah 5 dari 100 gelombang sesuai dengan kriteria Nordforsk tahun 1987. Pada analisis ini menggunakan bantuan Software Maxsurf Motion untuk mendapatkan RAO dari heave, pitch, lalu mendapatkan sudut fase dari heave, pitch, panjang gelombang, dan wave spectrum tiap wave encounter. Untuk titik tinjauan deck wetness yaitu pada bagian forecastle bulk carrier yaitu $83 \mathrm{~m}$ dari titik CG kapal. Dilakukan analisa deck wetness pada tinggi gelombang signifikan 4 meter dengan variasi heading atau arah datangnya gelombang yaitu $90^{\circ}$ (beam seas), $135^{\circ}$ (bow seas) dan $180^{\circ}$ (head seas).

\section{1) RAO bulk carrier}

Perhitungan RAO dihitung dengan mempertimbangkan variasi sudut hadap yaitu $90^{\circ}, 135^{\circ}$, dan $180^{\circ}$, dengan kecepatan dinas kapal 12 knot. Hasil dari RAO dapat dilihat pada Gambar 7 dan Gambar 8.

Pada Gambar 7 dan Gambar 8 dapat dilihat response amplitude operator (RAO) pada gerakan heave dan pitch dengan variasi sudut hadap yang berbeda - beda yaitu $90^{\circ}$, $135^{\circ}$, dan $180^{\circ}$. Berdasarkan gambar grafik juga dapat diketahui bahwa RAO heave terbesar terjadi ketika kapal mendapat gelombang dengan sudut hadap $180^{\circ}$ pada frekuensi gelombang $0.75 \mathrm{rad} / \mathrm{s}$ dengan simpangan terjauh mencapat $2.108 \mathrm{~m} / \mathrm{m}$.

RAO pitch terbesar terjadi ketika kapal mendapat gelombang dengan sudut hadap $180^{\circ}$ pada frekuensi

\section{Wave Encounter Spectrum}

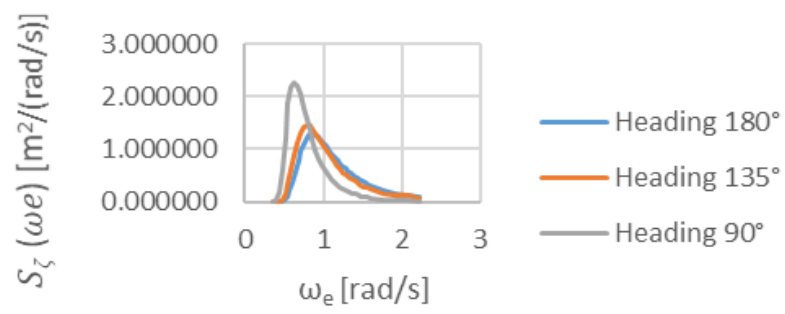

Gambar 9. Wave Encounter Spectrum Bulk Carrier

\section{Relative Bow Motion Spectrum}

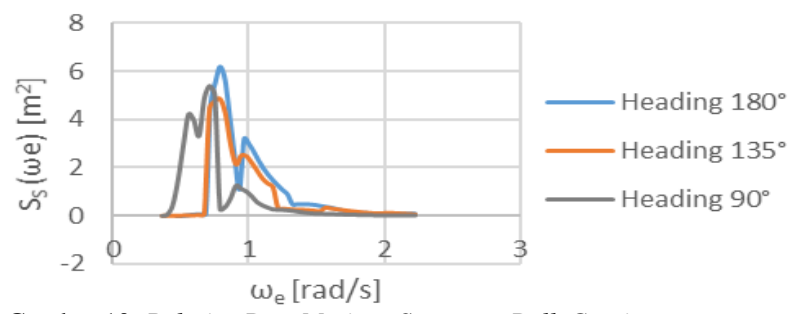

Gambar 10. Relative Bow Motiron Spectrum Bulk Carrier

Tabel 8.

Rekapitulasi Probabilitas Deck Wetness

\begin{tabular}{clrll}
\hline \hline No & Heading $\left[^{\circ}\right]$ & Probabilitas & Kriteria & Keterangan \\
\hline 1 & 180 & 0.039 & $<0.05$ & Memenuhi \\
2 & 135 & 0.014 & $<0.05$ & Memenuhi \\
3 & 90 & 0.012 & $<0.05$ & Memenuhi \\
\hline \hline
\end{tabular}

gelombang $0.466 \mathrm{rad} / \mathrm{s}$ dengan simpangan terjauh mencapat $0.035 \%$ m. Berdasarkan hasil RAO kapal pada keadaan heave dan pitch di berbagai sudut hadap, dapat disimpulkan bahwa gerakan heave dan pitch terbesar saat sudut hadapnya $180^{\circ}$.

\section{2) Spektrum Gelombang}

Spektrum gelombang pada pengerjaan studi ini adalah ITTC. Spektrum gelombang tersebut kemudian ditransformasikan menjadi spektrum gelombang encounter seperti terlihat pada Gambar 9. Terdapat 3 sudut hadap untuk menguji probabilitas deck wetness untuk tinggi gelombang signifikan $4 \mathrm{~m}$ yaitu, $90^{\circ}, 135^{\circ}$, dan $180^{\circ}$.

3) Relative Bow Motion Spectrum

Relative bow motion adalah gerakan pada bagian haluan kapal. Perhitungan relative bow motion diperlukan untuk menghitung deck wetness. Untuk perhitungan relative bow motion dengan menggunakan metode spectral didapat pada Gambar 10.

Didapat luasan dari relative bow motion spectrum dihitung dengan menggunakan simpson untuk selanjutnya digunakan dalam perhitungan deck wetness, pada Tabel 7 merupakan rekapitulasi perhitungan luasan spectrum relative bow motion.

4) Perhitungan Deck Wetness

Setelah didapatkan luasan tiap relative bow motion spectrum maka didapat perhitungan deck wetness dengan mempertimbangkan effective freeboard yaitu $8.39 \mathrm{~m}$ pada titik tinjauan. Pada Tabel 8 merupakan rekapitulasi perhitungan deck wetness.

Berdasarkan perhitungan yang ditinjau pada bagian forecastle yaitu 83 meter dari titik CG, maka kapal bulk carrier memenuhi kriteria seakeeping Nordforsk tahun 1987 dengan nilai probabilitas deck wetness tidak lebih dari 0.05 . 


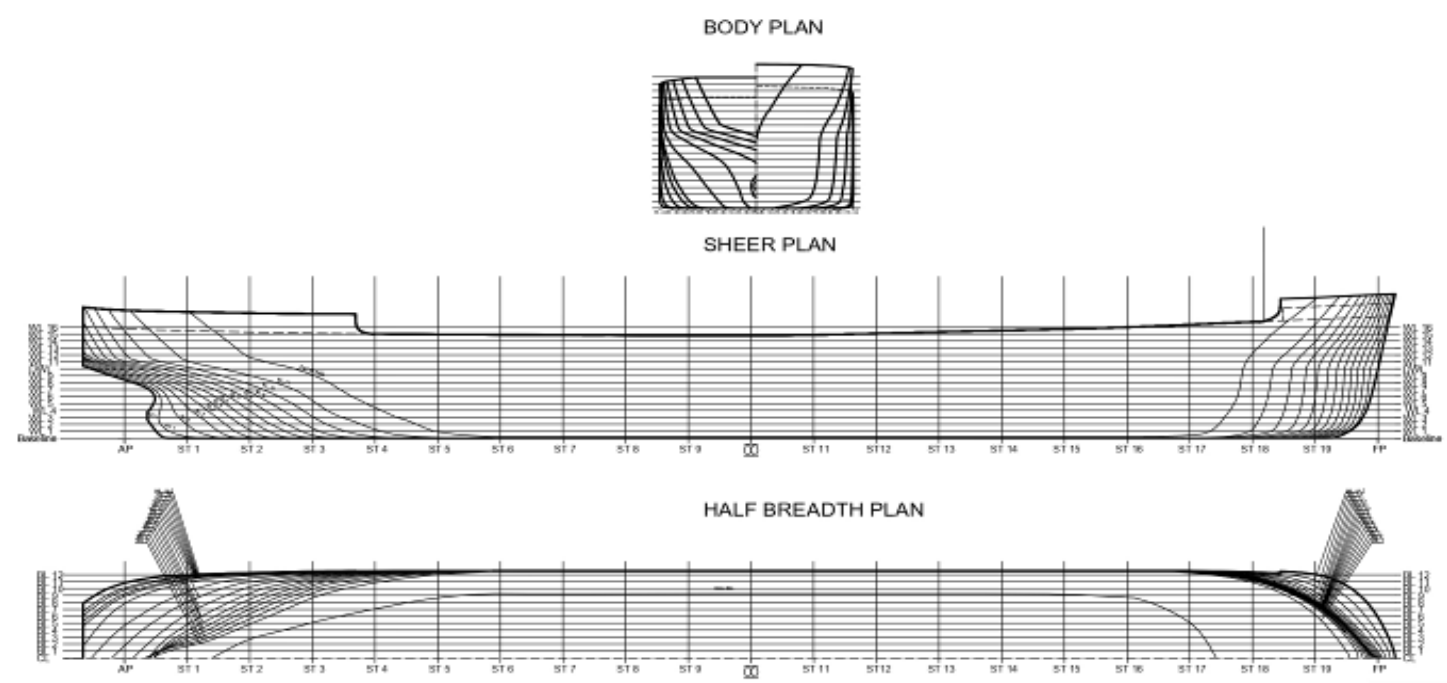

Gambar 11. Lines Plan dari bulk carrier
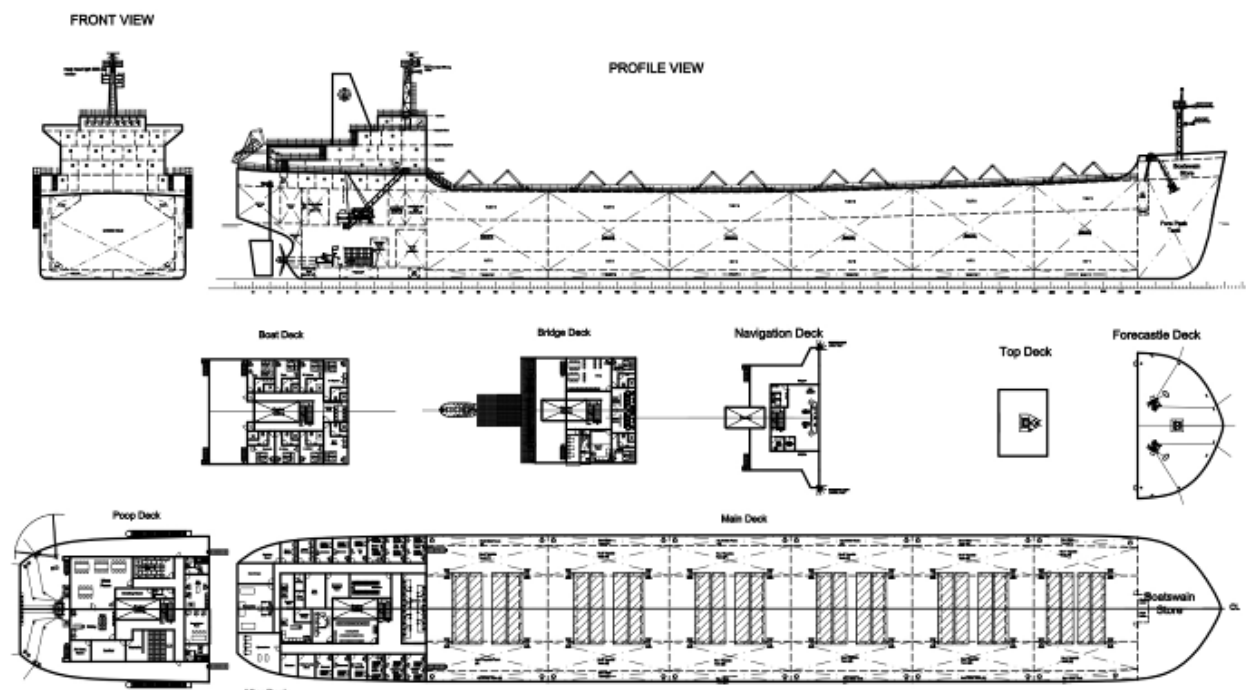

$\sin$
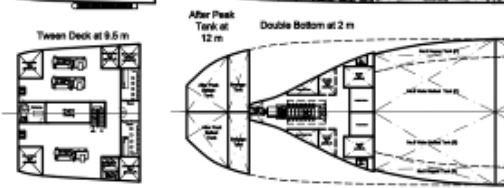

Gambar 12. General Arrangement dari bulk carrier

\section{Desain Lines Plan}

Lines plan atau rencana garis menyatakan bentuk potongan badan kapal yang memiliki tiga pandangan yaitu, body plan (secara melintang), sheer plan (secara memanjang), dan half-breadth plan (dilihat dari atas). Berikut merupakan lines plan dari bulk carrier dapat dilihat pada Gambar 11.

\section{1) Penentuan Penggunaan bulbous bow}

Dalam penentuan penggunaan bulbous bow terdapat beberapa pertimbangan agar kapal dapat menguntungkan dalam penggunaanya. Dalam penentuan bulbous bow pada kapal dapat ditunjukan dengan diagram Watson/Gilfillan terkait dengan hubungan froude number dan koefisien blok. Pada studi ini tidak menggunakan pada desainnya.

\section{1) Pemilihan Bentuk Haluan}

Pada pemilihan bentuk haluan kapal untuk studi ini kapal memiliki nilai CB 0.839 dan nilai Fn 0.1515. Sehingga berdasarkan diagram Watson/Gilfillan penggunaan bulbous bow tidak memberikan keuntungan untuk kapal. Oleh karena itu pada studi ini tidak menggunakan bulbous bow pada desainnya.

2) Penentuan Bentuk Midship

Untuk menentukan bentuk midship dapat ditinjau berdasarkan nilai CM kapal. Pada kapal bulk carrier nilai CM ini adalah 0.996. Untuk nilai CM 0.996 bentuk midship yang digunakan adalah bentuk $U$ karena memiliki beberapa keunggulan yaitu kapasitas ruang muat lebih besar, stabilitas kapal menjadi lebih baik, dan hambatan gelombang lebih kecil dibandingkan dengan bentuk $\mathrm{V}$.

3) Besar Jari - Jari Bilga

Penentuan bersar jari - jari bilga berdasarkan nilai dari $\mathrm{C}_{\mathrm{M}}$ kapal [4]. Pada studi ini jari - jari bilga yang digunakan adalah sebesar $1.25 \mathrm{~m}$.

4) Tinjauan Transom

Pemilihan bentuk transom kapal dapat mempengaruhi trim yang terjadi pada kapal [4]. Untuk pemilihan desain transom dipengaruhi oleh nilai dari Fn kapal, berdasarkan nilai Fn kapal yang telah dihitung bernilai 0.1515 maka bentuk transom berada di atas sarat kapal. 


\section{J. Desain General Arrangement}

General Arrangement atau rencana umum merupakan perencanaan ruangan yang dibutuhkan sesuai dengan fungsi dan perlengkapannya. General Arrangement dibuat berdasarkan lines plan yang telah dibuat sebelumnya General arrangement dari bulk carrier dapat dilihat pada Gambar 17.

\section{5) Penentuan Jumlah Sekat}

Penentuan sekat bulk carrier akan menggunakan 8 sekat diantaranya yaitu sekat belakang kamar mesin, sekat depan kamar mesin, sekat tubrukan dan 5 sekat ruang muat. Sekat tubrukan diletakkan pada jarak $12.6 \mathrm{~m}$ atau 21 jarak gading dari FP. Untuk sekat depan kamar mesin diletakkan pada jarak $24 \mathrm{~m}$, atau berjarak 41 jarak gading dari AP, lalu peletakkan sekat belakang kamar mesin pada jarak $5.4 \mathrm{~m}$ atau berjarak 9 jarak gading dari AP.

6) Penentuan Ruang Akomodasi

Pada perencanaan bulk carrier direncanakan memliki anak buah kapal dengan jumlah 28 orang, pada main deck terdapat terdapat 18 orang yaitu 3 oiler, 2 boys, 2 cadet, 2 fourth engineer, 4 seaman, 1 pump operator, 1 steward, 1 electrician, dan 2 motorman. Pada bagian poop deck terdapat 2 orang yaitu, 1 chief cook, dan 1 assistant cook, selanjutnya pada boat deck terdapat 6 orang yaitu, 1 chief officer, 1 second enginer, 1 third engineer, 1 second officer, 1 third officer, dan 1 doctor, Selanjutnya pada bridge deck terdapat 2 orang yaitu, 1 captain, dan 1 chief engineer.

7) Peralatan Kapal

Pada perencanaan Rencana Umum kapal, selain keperluan ruang akomodasi hal lain yang perlu diperhatikan adalah perlengkapan kapal sesuai dengan peraturan statutori yang ditetapkan. Dalam studi ini perlengkapan kapal yang ditinjau adalah Lampu Navigasi, seperti anchor light, mast head light, side light, dll. Lalu peralatan Keselamatan menggunakan free-fall lifeboat diletakkan dibagian belakang kapal.

\section{K. Desain Model 3D}

Desain 3D Model ini dibuat berdasarkan rencana umum. 3D Model dibuat untuk melihat gambaran kapal yang lebih realistik. Desain 3D model dapat dilihat pada Gambar 18.

\section{Perhitungan Biaya Pembangunan Kapal}

Dalam penelitian ini biaya pembangunan kapal dihitung berdasarkan harga tiap-tiap item di pasaran. Rekapitulasi biaya pembagunan disajikan dalam Tabel 9.

\section{KESIMPULAN}

Berdasarkan nilai kekurangan pasokan tiap tahun yang diambil paling besar yaitu 753861 ton batubara pada tahun 2018. Dan penentuan payload kapal dengan perencanaan kapal melakukan 28 round trip dari Kalimantan Selatan ke PLTU Pacitan sehingga didapatkan payload sebesar 26924 ton batubara.

Ukuran utama dan kecepatan setelah dilakukan pengecekan rasio dan kriteria adalah sebagai berikut: $\mathrm{L}_{\mathrm{PP}}=$ $162.7 \mathrm{~m} ; \mathrm{H}=14.2 \mathrm{~m} ; \mathrm{B}=25 \mathrm{~m} ; \mathrm{T}=10 \mathrm{~m}$; Vs $=12$ knot.

Didapat hasil perhitungan teknis sebagai berikut: Nilai hambatan total bulk carrier adalah $366.9 \mathrm{kN}$; Besar nilai MCR bulk carrier adalah 6225.1 HP atau $4578.699 \mathrm{~kW}$; Daya mesin yang digunakan yaitu $4770 \mathrm{~kW}$ atau $6396 \mathrm{HP}$; Perhitungan freeboard telah memenuhi sesuai dengan persyaratan ICLL 1966; Perhitungan stabilitas telah memenuhi persyaratan IS Code dan Grain Code; Perhitungan deck wetness bulk carrier pada tinggi gelombang signifikan $4 \mathrm{~m}$ telah memenuhi persyaratan sesuai dengan kriteria NORDFORKS 1987 dengan nilai probabilitas 0.039 untuk heading $180^{\circ}, 0.014$ untuk heading $135^{\circ}, 0.012$ untuk heading $90^{\circ}$.

Didapatkan desain Rencana Garis, Rencana Umum, dan Pemodelan 3D sesaui dengan tipe operasi.

Biaya pembangunan kapal bulk carrier adalah 7,580,172.32 USD atau Rp 106,327,835,163.90.

\section{UCAPAN TERIMA KASIH}

Penulis mengucapkan terima kasih kepada PT. PJB UBJOM Pacitan yang telah mengizinkan penulis untuk mengambil data untuk studi ini.

\section{DAFTAR PUSTAKA}

[1] E. I. Putra, "Analisis Penerapan Continoun Coal Transport Mode Untuk Angkutan Batubara di Sungai," Institut Teknologi Sepuluh Nopember, 2012.

[2] H. S. dan E. S. M, Pengantar Oseanografi. Jakarta: Universitas Indonesia Press, 2006.

[3] T. Lamb and Society of Naval Architects and Marine Engineers, Ship Design and Construction. Jersey City, New Jersey: Society of Naval Architects and Marine Engineers, 2003.

[4] H. Schneekluth and V. Betram, Ship Design for Efficiency and Economy, 2nd ed. Oxford, 1998. 